\title{
Do topical repellents divert mosquitoes within a community?
}

\author{
Marta Maia ${ }^{1,2^{*}}$, Peter Sangoro ${ }^{1,2}$, Max Thele ${ }^{3}$, Elizabeth Turner ${ }^{4}$, Sarah Moore ${ }^{1,2}$ \\ From Challenges in malaria research \\ Basel, Switzerland. 10-12 October 2012
}

\section{Background}

Repellents are compounds which interfere with the mosquito's olfactory system hindering them to identify their hosts and succeeding in taking a blood-meal [1]. However, repellents do not eliminate the host-seeking mosquitoes, they simply reduce human-vector contact. Consequently, there is a possibility that individuals, who do not use repellents, experience more bites than usual because mosquitoes are diverted from the repellent users. The objective of this study was to measure if diversion occurs from households that use repellents to those that don't within a community with incomplete topical repellent coverage.

\section{Materials and methods}

An interventional study was performed in three villages of southern Tanzania using 15\%-DEET (N,N-Diethyl-metatoluamide) and a placebo lotion. Three coverage scenarios were investigated: complete repellent coverage (all households were given $15 \%$-DEET), incomplete repellent coverage (80\% of households were given DEET- $15 \%$ and $20 \%$ were given a placebo lotion) and no repellent coverage (all households were given a placebo lotion). The coverage scenarios were rotated between villages. Mosquito densities were measured through aspiration of indoor and outdoor resting mosquitoes respective to each enrolled household. Data was analysed using mixed-effects models and the no coverage scenario was used as reference.

\section{Results}

Placebo users living in a village where $80 \%$ of the households used $15 \%$-DEET were likely to have nearly three times more mosquitoes $(p<0.001)$ resting in their dwellings in comparison to households in a village where nobody uses repellent (Table 1).

\section{Conclusions}

There is strong evidence that mosquitoes are diverted between households that use repellent to those that don't. This study arises questions on health equity associated with repellent usage. Policy makers should take into consideration these results while devising vector control programs, as less privileged individuals are likely to suffer more mosquito bites and therewith be more exposed to vector-borne diseases if universal coverage is not reached.

Table 1 Incidence rate ratios (IRR), model estimated means ${ }^{1}$, confidence intervals and p-values of mean number of mosquitoes aspirated per night per household by treatment group

\begin{tabular}{lcccc}
\hline & IRR & Mean ${ }^{\mathbf{1}}$ & $\mathbf{9 5 \%} \mathbf{C l}$ & p-value \\
\hline No coverage & 1 & 4.97 & {$[3.77-6.16]$} & - \\
Complete coverage & 0.5 & 2.49 & {$[1.76-3.22]$} & $<0.001$ \\
$80 \%$ Coverage (repellent users) & 0.69 & 3.45 & {$[2.83-4.06]$} & 0.015 \\
$80 \%$ Coverage (non repellent users) & 2.87 & 14.25 & {$[9.74-18.76]$} & $<0.001$ \\
\hline
\end{tabular}

'Department of Disease Control, London School of Hygiene \& Tropical

Medicine, London, WC1E 7HT, UK

Full list of author information is available at the end of the article

(c) 2012 Maia et al; licensee BioMed Central Ltd. This is an Open Access article distributed under the terms of the Creative Commons 


\section{Acknowledgments}

We would like to thank the people of Sanje, Upper and Lower Matete for their support during the project.

\section{Author details}

'Department of Disease Control, London School of Hygiene \& Tropical Medicine, London, WC1E 7HT, UK. ${ }^{2}$ Environmental Group, Ifakara Health Institute, Bagamoyo, United Republic of Tanzania. ${ }^{3}$ Institut Franco-Allemand de Recherche de Saint Louis, St. Louis, France. ${ }^{4}$ Departments of Biostatistics and Bioinformatics, Duke Global Health Institute, NC, USA.

\section{Published: 15 October 2012}

\section{Reference}

1. Davis EE: Insect repellents: concepts of their mode of action relative to potential sensory mechanisms in mosquitoes (Diptera: Culicidae). $J$ Med Entomol 1985, 22:237-243.

doi:10.1186/1475-2875-11-S1-P120

Cite this article as: Maia et al:: Do topical repellents divert mosquitoes within a community? Malaria Journal 2012 11(Suppl 1):P120.

\section{Submit your next manuscript to BioMed Central} and take full advantage of:

- Convenient online submission

- Thorough peer review

- No space constraints or color figure charges

- Immediate publication on acceptance

- Inclusion in PubMed, CAS, Scopus and Google Scholar

- Research which is freely available for redistribution

Submit your manuscript at www.biomedcentral.com/submit 